\title{
A new Ophryotrocha species (Polychaeta: Dorvilleidae) from circalittoral seabeds of the Cantabrian Sea (north-east Atlantic Ocean)
}

\author{
JORGE NÚÑEZ ${ }^{1}$, RODRIGO RIERA ${ }^{2}$ AND YOLANDA MAGGIO ${ }^{1}$ \\ ${ }^{1}$ Benthos Laboratory, Department of Animal Biology, University of La Laguna, 38206 La Laguna, Tenerife, Canary Islands, Spain, \\ ${ }^{2}$ Centro de Investigaciones Medioambientales del Atlántico (CIMA SL), Arzobispo Elías Yanes, 44, 38206 La Laguna, Tenerife, \\ Canary Islands, Spain (Present address: Department of Biodiversity, Qatar Environment and Energy Research Institute (QEERI), \\ 5825 Doha, Qatar)
}

\begin{abstract}
One new dorvilleid species belonging to the genus Ophryotrocha Claparede \& Mecznikow, 1869 is described. The studied material was collected in circalittoral seabeds (70-100 $\mathrm{m}$ depth) in the Cantabrian Sea (north-east Atlantic Ocean). The new species Ophryotrocha cantabrica is characterized by having well-developed antennae and palps, parapodia with long dorsal cirrus, sub-triangular acicular lobes and inferior chaetal lobe well-developed, as well as the presence of P-type maxillae and bifid mandibles slightly tagged. The most closely related Ophryotrocha species are O. longidentata Josefson, 1975 and O. lobifera Oug, 1978; however, both species have biarticulated palps. Other differences with O. cantabrica sp. nov. are: body size and shape, parapodia morphology and number of setae, as well as the shape of mandibles and maxillae.
\end{abstract}

Keywords: Polychaeta, Dorvilleidae, Ophryotrocha, circalittoral, Cantabrian Sea, Atlantic Ocean

Submitted 12 April 2013; accepted 5 July 2013; first published online 6 August 2013

\section{INTRDDUCTION}

In the last decades, many new species of Dorvilleidae have been described worldwide (Eibye-Jacobsen \& Kristensen, 1994), especially from recently sampled environments, such as deep-sea methane seep sediments (Thronhill et al., 2012). Moreover, interstitial species living in shallow marine environments have still been discovered year after year (e.g. Åkesson, 1973, 1976; Brito \& Núñez, 2003).

The genus Ophryotrocha is one of the largest dorvilleid genera ( $\sim$ o species), and traditionally has been classified as opportunistic, with some commensal species of decapods and holothuroids (Martín \& Britayev, 1998), being abundant also in polluted sediments (Rouse \& Pleijel, 2001; Paxton \& Davey, 2010). Thus, it has been considered a target genus in monitoring assessment studies, being classified as a species resistant to pollution (Borja et al., 2000). However, several recently described species of this genus have been recovered from pristine environments, from the US Atlantic slope and rise (Hilbig \& Blake, 1991), and deep-sea whale- and woodfalls (Wiklund et al., 2009, 2012). Even some species from experimental monoculture studies have been identified as new taxa after a detailed examination of their jaw structure (e.g. Åkesson \& Paxton, 2005), as well as, genetic analysis (Heggøy et al., 2007), which showed the presence of sibling species (Paxton \& Àkesson, 2010, 2011).

Eight Ophryotrocha species have been recorded from Iberian Peninsula waters (Campoy, 1982; Martín et al., 1991;

Corresponding author:

J. Núñez

Email: janunez@ull.es
Paxton \& Åkesson, 2007, 2010, 2011). However, new records are expected in the near future from field surveys carried out on deep-sea bottoms and biodiversity hotspots, such as volcanic marine caves. The new species Ophryotroch a cantabrica sp. nov. has been collected in circalittoral waters, 70-100 m deep, in the Cantabrian Sea, and their diagnostic characters are well developed antennae and palps, parapodia with long dorsal cirrus, sub-triangular acicular lobes and inferior chaetal lobe

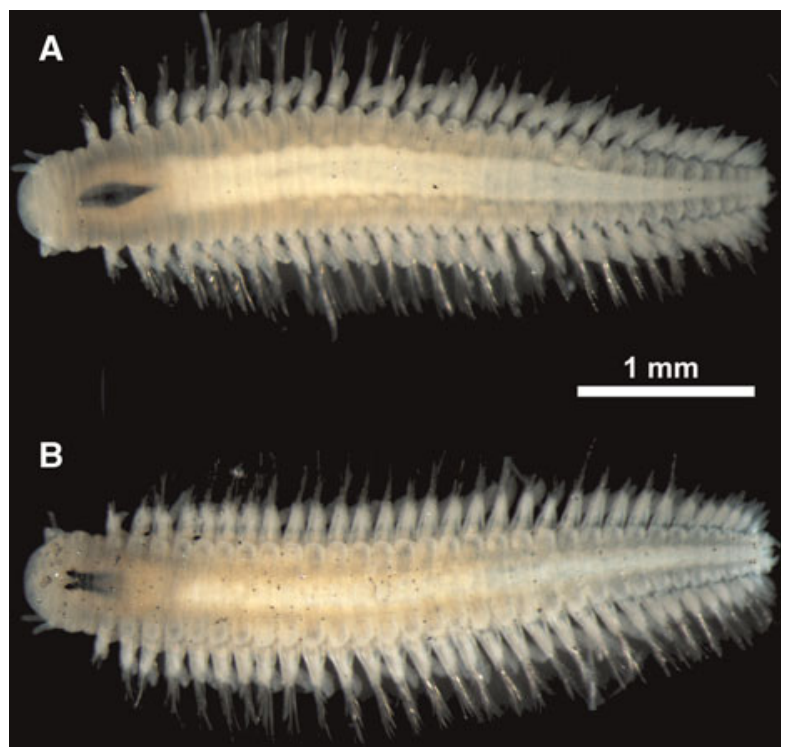

Fig. 1. Ophryotrocha cantabrina sp. nov.: (A), complete specimen, dorsal view; (B) complete specimen, ventral view. 
well-developed, as well as the presence of P-type maxillae and bifid mandibles slightly tagged.

\section{MATERIALSAND METHODS}

The material studied was collected during the research cruise 'Fauna II' of project 'Fauna Ibérica' in the Bay of Biscay, in the summer of 1991. Samples were collected from circalittoral seabeds (70-100 m depth) by means of a Bou de varas grab. Samples were fixed with $10 \%$ formaldehyde in seawater, and the specimens were transferred to $70 \%$ ethanol. Some specimens were mounted whole in permanent microscopic slides in glycerine jelly; examination was made by means of a compound microscope provided with differential interference contrast optics (Nomarski). Drawings were made to scale with a camera lucida drawing tube. Specimens were photographed with a digital camera (Olympus $\mathrm{DP}_{70}$ ) coupled to a stereomicroscope (Olympus SZX12).
The type material is deposited at the Museo Nacional de Ciencias Naturales de Madrid (MNCN).

\section{RESULTS}

SYSTEMATICS

DORVILLEIDAE Chamberlin 1919

Ophryotrocha cantabrica sp. nov.

(Figures 1-3)

\section{TYPE MATERIAL}

'Fauna II', Station 114A, 15 June 1991, Gijón (Asturias), initial coordinates $43^{\circ} 37.71^{\prime} \mathrm{No}^{\circ} 37.59^{\prime} \mathrm{W}$, final coordinates $43^{\circ} 38.36^{\prime} \mathrm{No}^{\circ} 39.78^{\prime} \mathrm{W}, \quad 72-74 \mathrm{~m}$ deep, muddy sandy seabed, holotype (MNCN 16.0/14704) and 38 paratypes (MNCN 16.01/13633); Station 150A, 22 June 1991, Zumaya
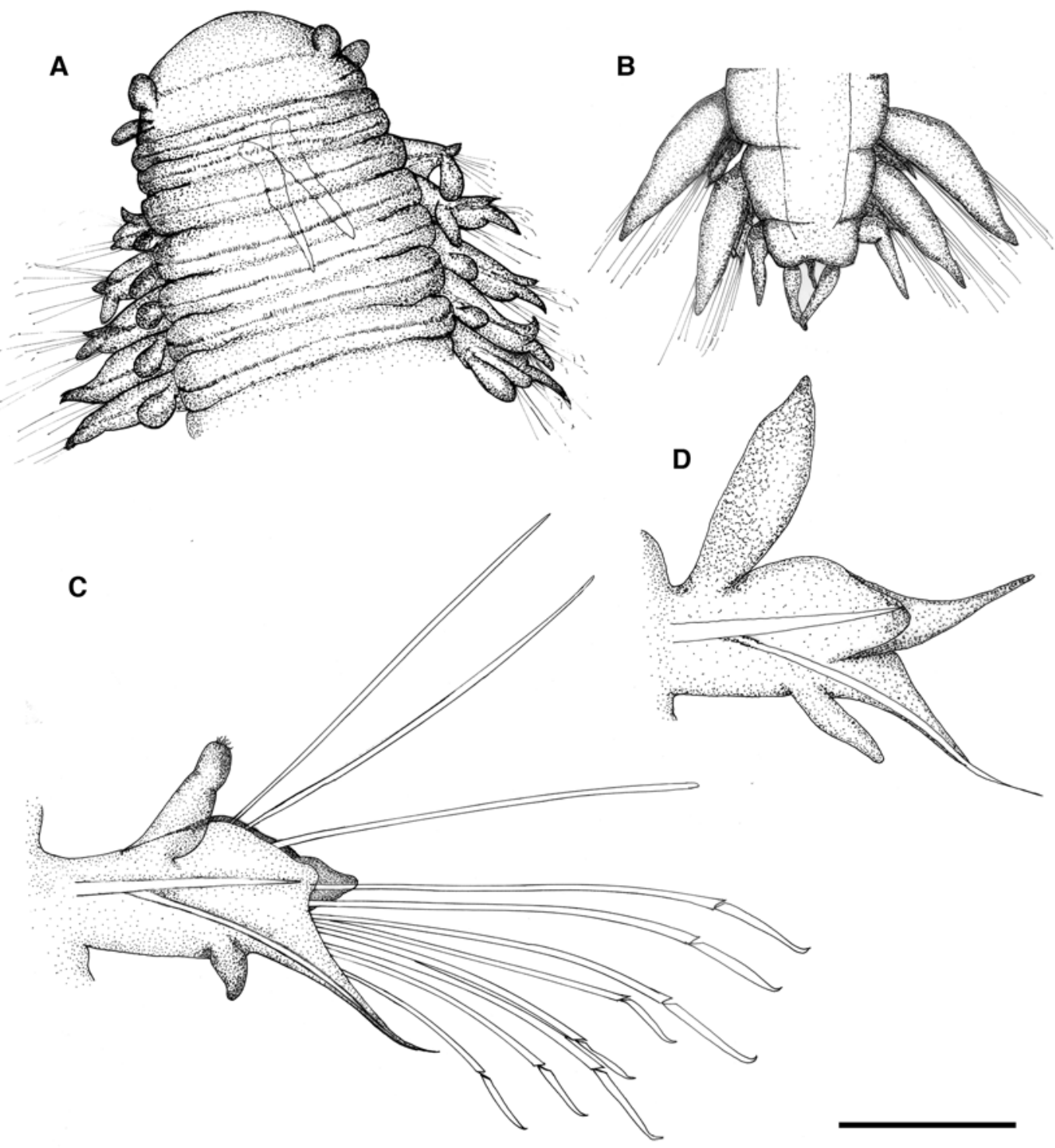

Fig. 2. Ophryotrocha cantabrina sp. nov.: (A) anterior end, dorsal view; (B) posterior end, dorsal view; (C) anterior parapodia, lateral view; (D) middle parapodium without chaetae, lateral view. Scale bars: A, $370 \mu \mathrm{m}$; B, $320 \mu \mathrm{m}$; C,D, $77 \mu \mathrm{m}$. 


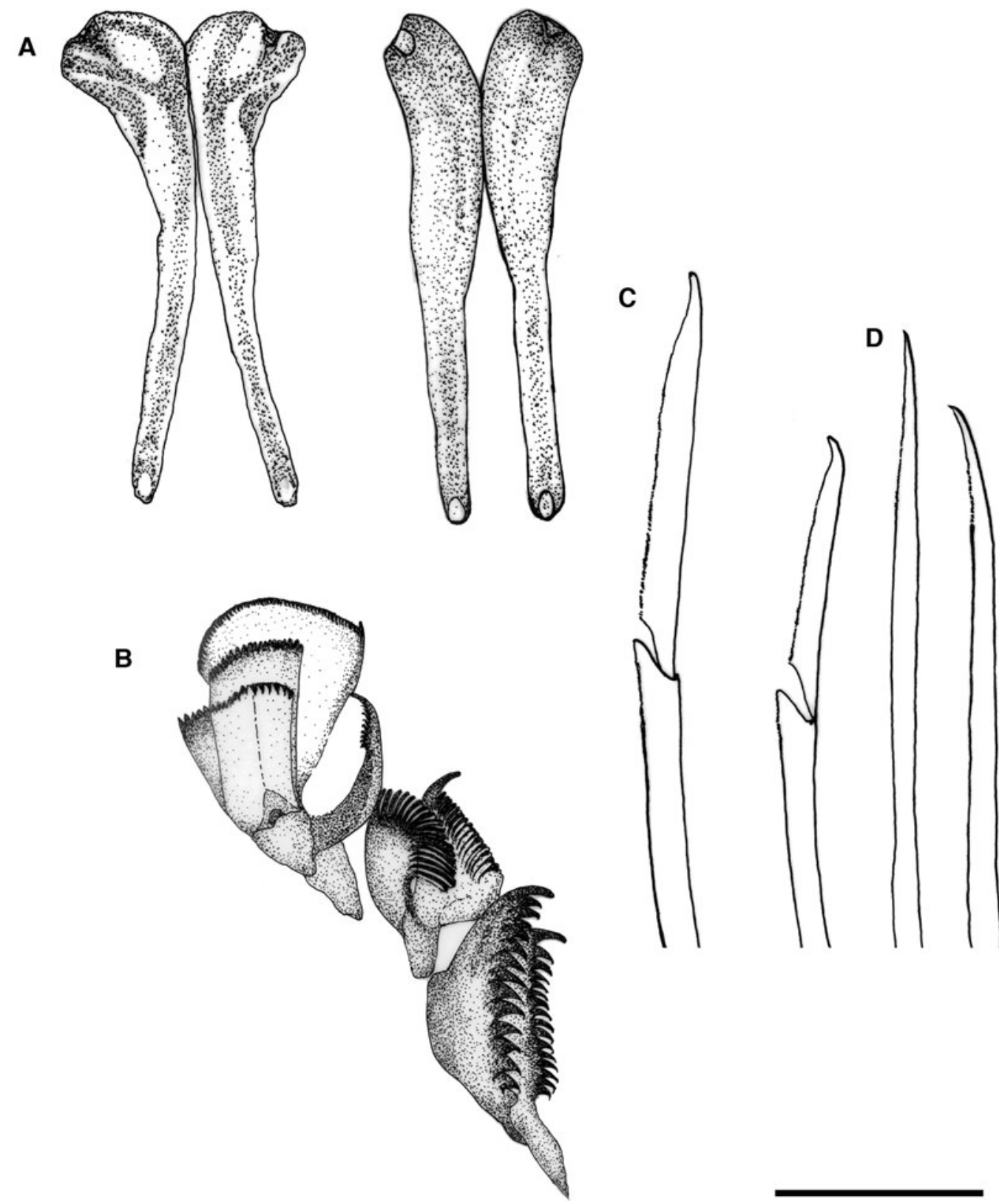

Fig. 3. Ophryotrocha cantabrina sp. nov.: (A) mandibles; (B) P-maxillae; (C) heterogomph falciger chaetae; (D) simple chaetae. Scale bars: A, $100 \mu$ m; B, $89 \mu$ m; $\mathrm{C}, \mathrm{D}, 24 \mu \mathrm{m}$.

(Guipúzcoa), initial coordinates $43^{\circ} 22.18^{\prime} \mathrm{No}^{\circ} 15.00^{\prime} \mathrm{W}$, final coordinates $43^{\circ} 23.14^{\prime} \mathrm{No}^{\circ}{ }^{\circ} 15.21^{\prime} \mathrm{W}, 93-101 \mathrm{~m}$ deep, sandy seabed with shells, 7 specimens (MNCN 16.9/13680).

\section{DESCRIPTION}

Body shape elongated, of generally uniform width, from the middle part of the body they gradually taper posteriorly (Figure 1). Holotype complete, $4.2 \mathrm{~mm}$ long, $0.6 \mathrm{~mm}$ wide (without parapodia) for 28 chaetigers, other complete specimen (paratype) $2.5 \mathrm{~mm}$ long, $0.5 \mathrm{~mm}$ wide for 22 chaetigers Colour in alcohol opaque white. Prostomium rounded without discernible eyes, a pair of ovoid to digitiform dorsal antennae and a pair of ventro-lateral palps similar to antennae (Figure 2A). Two peristomial achaetous segments, twice as long as the following chaetigers, both rings circumscribed by a ciliary band (Figure 2A). Mandibles long and slender
(143-280 $\mu \mathrm{m}$ long), distally slightly bifid without serration in anterior part edge (Figure $3 \mathrm{~A}$ ). Maxillary apparatus of P-type only, maxillae composed of a posterior large piece with teeth (forceps) and seven anterior free denticles on either side (Figure $3 \mathrm{~B}$ ); denticles on each side in two closely situated, with small dorsal teeth, denticles of outer row with an additional larger and strong lateral tooth. Forceps of adult specimens with distal fang and 13-15 teeth, distal fang not much larger than other teeth; D1 similar to forceps with larger teeth, $\mathrm{D}_{2}-\mathrm{D}_{3}$ with distal fang and cutting edge coarsely serrated, $\mathrm{D}_{4}-\mathrm{D}_{7}$ with uniform serrated edge (Figure 3B).

Setigers circumscribed by a ciliary band. Parapodia uniramous with dorsal and ventral cirri (Figure $2 \mathrm{C}, \mathrm{D}$ ); dorsal cirrus more or less developed, of ovoid in anterior part to foliose in the rest of the body (Figure $2 \mathrm{D}$ ), ventral cirrus 
short (Figure $2 \mathrm{C}$ ). Two conical chaetiger lobes, with strong aciculum, and one ventral (sub-acicular), longer pointed lobe, with a thinner supporting aciculum protrudes from tip of lobe, similar to simple chaeta (conical chaetal lobe) (Figure $2 \mathrm{C}, \mathrm{D}$ ). Chaetae long, divergent and forming a fan. Three to seven supra-acicular simple chaeta smooth with hooked unidentate distal parts (Figure ${ }_{3} \mathrm{D}$ ), eight to nine subacicular heterogomph compound chaetae, unidentate blades with slight serration and hooked tips (Figure ${ }_{3} \mathrm{C}$ ), gradation blade length of $48 \mu \mathrm{m}$ dorsal chaeta to $32 \mu \mathrm{m}$ ventral most chaeta, shaft also with slight serration; the sub-acicular conical chaetal lobe holds one simple chaeta (Figure $2 \mathrm{C}, \mathrm{D}$ ).

Pygidium wider than long, with terminal anus and two laterally digitiform anal cirri, and an unparied conical appendage attached ventrally (median stylus) (Figure $2 \mathrm{~B}$ ).

Some specimens had eggs with a maximum diameter of $80-100 \mu \mathrm{m}$ beginning about chaetiger 4 to 11 (female with 19 chaetigers).

\section{ETYMOLOGY}

The specific named refers to the type locality geographical distribution (Cantabrian Sea).

\section{DISTRIBUTION}

North-east Atlantic Ocean, Cantabrian Sea, Bay of Biscay (Asturias and Guipúzcoa).

\section{DISCUSSIDN}

Ophryotrocha cantabrica sp. nov. differs from the remaining Ophryotrocha species by having the following characteristics: well-developed antennae and palps, lacking eyes, parapodia with long dorsal cirrus, sub-triangular acicular lobes and inferior chaetal lobe well-developed, supported by inferiormost chaeta, and the presence of bifid mandibles and P-type maxillae. Ophryotrocha longidentata Josefson, 1975 (Josefson, 1975) and O. lobifera Oug, 1978 (Oug, 1978) are two species that more closely resemble $O$. cantabrica sp. nov. in body shape and the morphology of the parapodia; both species have palps biarticulated, while in O. cantabrica sp. nov. are simple. Ophryotrocha lobifera differs in having prominent dorsal and ventral thickenings to parapodia. In the parapodia of $O$. cantabrica sp. nov. the dorsal cirrus is much more developed, especially in the posterior part. The shape of the mandibles differs greatly among the three species, in O. longidentata has expansions wing with smooth edge and without teeth, while O. lobifera has the serrated edge and O. cantabrica distally slightly bifid without serration in the anterior part of the edge.

In relation to reproduction, we found only one ovigerous female, whereas we have not observed sperm in any of the studied specimens. The egg size ranges from $50 \mu \mathrm{m}$ in $O$. longidentata to $120 \mu \mathrm{m}$ in O. lobifera, being intermediate in O. cantabrica sp. nov. (100 $\mu \mathrm{m})$.

The three species inhabit soft substrates at circalittoral depths $(50-100 \mathrm{~m})$, O. longidentata inhabits muds and fine sands, O. lobifera in black muds with sulphide and O. cantabrica $\mathrm{sp}$. nov. in muddy sandy and sandy substrates with shell fragments. The three species are considered meiofauna because of their body sizes and habitats.

\section{ACKNDWLEDGEMENTS}

We are grateful to all researchers and staff of the National Museum of Natural Sciences (MNCN-Madrid) involved in oceanographic surveys where the Ophryotrocha specimens were collected.

\section{FINANCIAL SUPPDRT}

This work is a contribution of the Project 'Fauna Ibérica X, subproject CGL 2010-22267-C07-03' funded by the Research Supreme Council.

\section{REFERENCES}

Åkesson B. (1973) Reproduction and larval morphology of five Ophryotrocha species (Polychaeta, Dorvilleidae). Zoologica Scripta 2, $145-155$.

Åkesson B. (1976) Morphology and life cycle of Ophryotrocha diadema, a new polychaete species from California. Ophelia 15, 22-35.

Åkesson B. and Paxton H. (2005) Biogeography and incipient speciation in Ophryotrocha labronica (Polychaeta, Dorvilleidae). Marine Biology Research 1, 127-139.

Borja A., Franco J. and Pérez V. (2000) A marine biotic index to establish the ecological quality of soft-bottom benthos within European estuarine and coastal environments. Marine Pollution Bulletin 40, 11001114 .

Brito M.C. and Núñez J. (2003) Three new interstitial dorvilleids (Annelida: Polychaeta) from the Cymodocea nodosa meadows of the Canary Islands. Hydrobiologia 496, 27-34.

Campoy A. (1982) Fauna de España. Fauna de Anélidos Poliquetos de la Península Ibérica. EUNSA (Ediciones de la Universidad de Navarra). Publicaciones de Biología de la Universidad de Navarra, Serie Zoológica 7, 1-781.

Eibye-Jacobsen D. and Kristensen R.M. (1994) A new genus and species of Dorvilleidae (Annelida, Polychaeta) from Bermuda, with a phylogenetic analysis of Dorvilleidae, Iphitimidae and Dinophilidae. Zoologica Scripta 23, 107-131.

Heggøy K.K., Schander C. and Åkesson B. (2007) The phylogeny of the annelid genus Ophryotrocha (Dorvilleidae). Marine Biology Research 3 , $412-420$.

Hilbig B. and Blake J.A. (1991) Dorvilleidae (Annelida: Polychaeta) from the US Atlantic slope and rise. Description of two new genera and 14 new species, with a generic revision Ophryotrocha. Zoologica Scripta $20,147-183$

Josefson A. (1975) Ophryotrocha longidentata, sp. n. and Dorvillea erucaeformis (Malmgren) (Polychaeta, Dorvilleidae) from the west coast of Scandinavia. Zoologica Scripta 4, 49-54.

Martín D. and Britayev T.A. (1998) Symbiotic polychaetes: review of known species. Oceanography and Marine Biology: an Annual Review 36, 217-340.

Martín D., Abelló P. and Cartes J. (1991) A new species of Ophryotrocha (Polychaeta: Dorvilleidae) commensal of Geryon longipes (Crustacea: Brachyura) from the Western Mediterranean Sea. Journal of Natural History 25, 279-292.

Oug E. (1978) New and lesser known Dorvilleidae (Annelida, Polychaeta) from Scandinavian and Northeast American waters. Sarsia 63, 285-303. 
Paxton H. and Åkesson B. (2007) Redescription of Ophryotrocha puerilis and O. labronica (Annelida, Dorvilleidae). Marine Biology Research 3, $3-19$.

Paxton H. and Åkesson B. (2010) The Ophryotrocha labronica group (Annelida: Dorvilleidae)-with the description of seven new species. Zootaxa 2713, 1-24.

Paxton H. and Åkesson B. (2011) The Ophryotrocha diadema group (Annelida: Dorvilleidae) with the description of two new species. Zootaxa 3092, 43-59.

Paxton H. and Davey A. (2010) A new species of Ophryotrocha (Annelida: Dorvilleidae) associated with fish farming at Macquarie Harbour, Tasmania, Australia. Zootaxa 2509, 53-61.

Rouse G.W. and Pleijel F. (2001) Polychaetes. Oxford: Oxford University Press.

Thronhill D.J., Struck T.H., Ebbe B., Lee R.W., Mendoza G.F., Levin L.A. and Halanych K.M. (2012) Adaptive radiation in extremophilic
Dorvilleidae (Annelida): diversification of a single colonizer or multiple independent lineages? Ecology and Evolution 2, 1958-1970.

Wiklund H., Glover A.G. and Dahlgren T.G. (2009) Three new species of Ophryotrocha (Annelida: Dorvilleidae) from a whale-fall in the North-East Atlantic. Zootaxa 2228, 43-56.

and

Wiklund H., Altamira I.V., Glover A.G., Smith C.R., Baco A.R. and Dahlgren G. (2012) Systematics and biodiversity of Ophryotrocha (Annelida, Dorvilleidae) with description of six new species from deep-sea whale-fall. Systematics and Biodiversity 10, 243-259.

\section{Correspondence should be addressed to:}

J. Núñez

Benthos Laboratory, Department of Animal Biology University of La Laguna, 38206 La Laguna

Tenerife, Canary Islands, Spain email: janunez@ull.es. 